\title{
Can auxins improve rooting of propagules and establishment of cashew clones?
}

\author{
Olawale Mashood ALIYU* ${ }^{\star 1,2}$, Keji Emmanuel DADA ${ }^{1}$, Lateef Akinkunle HAMmED ${ }^{1}$
}

${ }^{1}$ Cocoa Res. Inst. Nigeria, PMB 5244, Ibadan, Nigeria walealiyu@mail.com aliyu@ipk-gatersleben.de

2 Dep. Cytogenet. Genome Ana., Inst. Plant Genet. Crop Plant Res. (IPK),

Corrensstraße 3, D-06466 Gatersleben Germany
${ }^{*}$ Correspondence and reprints

Received 27 November 2008 Accepted 10 June 2009

Fruits, 2010, vol. 65, p. 307-314 (C) 2010 Cirad/EDP Sciences All rights reserved DOI: $10.1051 /$ fruits/2010026 www.fruits-journal.org

RESUMEN ESPAÑOL, p. 314

\section{Can auxins improve rooting of propagules and establishment of cashew clones?}

Abstract - Introduction. Cashew production has been on a decline due to poor yield resulting from poor quality traits of open-pollinated seedling populations that were used to establish plantations. Clones established from outstanding individuals through air-layering root poorly and are not likely to survive transplanting, thus clonal propagation by air-layering has been of little value for cashew propagation. Materials and method. To improve the rooting percentages of air-layering, three auxins (IBA, NAA and IAA) were applied at six concentrations $[(0,1,2,3,4$ and 5$) \%]$ on four cashew genotypes. Results and discussion. Significant improvement was recorded in terms of layer take, number of roots per layer, number of days to rooting, length of roots and percentage of surviving clones after transplanting. Improvement varied between the different auxins, concentrations and genotypes. We observed that degree of rooting was genotype-specific and influenced by auxin type and specific concentration. Our data showed that, among the auxins tested, IBA was most effective, with optimum performance at the $2 \%$ concentration. Conclusion. Using auxins made it possible to significantly improve the rooting and survival of cashew propagules; however, to achieve sufficient rooting and better establishment after transplanting, auxin treatment should not exceed $3 \%$ concentration. This intervention would help alleviate the problem of clonal establishment in cashew.

\section{Nigeria / Anacardium occidental / vegetative propagation / layering / auxins / plant establishment}

\section{Les auxines peuvent-elles améliorer l'enracinement des marcottes et l'établissement de clones d'anacardier?}

Résumé - Introduction. La production de noix de cajou est en déclin du fait de rendements insuffisants imputables à la mauvaise qualité des populations d'anacardiers issues de semis obtenus par pollinisation libre et utilisées pour établir les plantations. Les clones établis à partir d'individus sélectionnés, obtenus par marcottage aérien, racinent mal et ne sont pas aptes à survivre à la transplantation; de ce fait, la propagation clonale par marcottage aérien est peu efficace pour la propagation de l'anacardier. Matériel et méthodes. Pour améliorer les pourcentages d'enracinement à partir de marcottage aérien, trois auxines (AIB, ANA et AIA) ont été appliquées à six concentrations différentes [(0, 1, 2, 3, 4 et 5) \%] sur quatre génotypes d'anacardiers, deux d'origine indienne et deux d'origine brésilienne. Résultats et discussion. Des améliorations significatives ont été enregistrées en ce qui concerne le prélèvement de marcottes, le nombre de racines par marcotte, le nombre de jours pour l'enracinement, la longueur des racines et le pourcentage de survie des clones après repiquage. Les améliorations ont varié selon les auxines expérimentées, les concentrations utilisées et les génotypes testés. Nous avons observé que le degré d'enracinement était spécifique du génotype et influencé par le type auxine et sa concentration. Nos résultats ont montré que, des trois auxines testées, l'AIB était la plus efficace avec un effet optimal à une concentration de $2 \%$. Conclusion. L'utilisation des auxines a permis d'améliorer significativement l'enracinement et la survie des marcottes d'anacardiers ; toutefois, pour obtenir un enracinement suffisant et une meilleure reprise après repiquage, l'auxine ne devrait pas être appliquée à une concentration supérieure à $3 \%$. Cette intervention permettrait de réduire le problème de l'établissement des anacardiers au champ.

Nigéria / Anacardium occidental /multiplication végétative / marcottage / auxine / établissement de la plante 


\section{Introduction}

Cashew (Anacardium occidentale) is widely cultivated in the tropical regions of the world today. Although cashew is native to Brazil [1, 2], major production is centralized in the third world countries such as Vietnam, Nigeria, India, Brazil and Tanzania with current (2007) annual raw nut production of (961 000, 660000,620 000, 176384 and 92000$) \mathrm{t}$, respectively [3].

Cashew is grown primarily for its kernels, that are highly nutritive and low in cholesterol. The most important markets for cashew kernels are in Europe and the United States of America. Other economic uses for cashew include production of juice, wine, vinegar and dry gin from the apple (the apple-like fruit that supports the cashew "nut"), and cashew nut shell liquid (CNSL), an industrial oil from the shell

The crop provides employment for about three million households in Africa, especially rural women, in major producing countries such as Mozambique, Nigeria, Guinea Bissau and Tanzania [4]. It has been opined in several fora organized by the African Cashew Alliance (ACA) that cashew processing can generate annual revenues for Africa as high as US $\$ 500 \mathrm{M}$ by 2015, of which $40 \%$ would go to wages for manual labor.

In Nigeria, cashew cultivation has been on the increase, with annual cultivation of between (5 000 and 8000$)$ ha since 2000 Its contribution to the Nigerian economy has been reviewed $[5,6]$. In particular, cashew production is a major source of cash income to many smallholder farmers in the central and northern parts of the country and has been the second most exported crop, i.e., next to cocoa. In spite of the vast economic importance of the crop, cashew nut production has been declining in major producing countries due to poor yields.

Cashew is a cross-pollinated plant and usually propagated from nuts, thus wide genetic variability among the open-pollinated progenies has resulted in poor yields [7-9]. However, with regard to large-scale propagation and conservation of selected genetic characters, sexual reproduction and out-breeding pose a risk of losing valued desirable quality characteristics across generations. Studies have shown that only $20 \%$ of trees planted from open population seeds produce $80 \%$ of the yield from a hectare of cashew [8, 9] which, therefore, becomes a limitation for establishing economically viable commercial orchards. Hence, vegetative propagation offers an opportunity by which quality characteristics of desirable mother trees can be maintained perpetually, thus becoming the preferred choice for raising cashew propagules [10].

Various clonal propagation techniques such as patch budding and grafting [2, 10], cutting and air-layering [11-13], and use of micro-shoot explants in in vitro propagation [14] have been attempted in cashew. However, poor rooting of propagules hampers their usefulness for large-scale cashew planting programs. Our preliminary work showed that post-planting die-back of propagules hindered easy adoption of budding and grafting propagation techniques despite the fact that we recorded $44 \%$ and $58 \%$ success rates, respectively. Similarly, trials on air-layering showed that $65 \%$ of the air-layered plants sprouted and less than $8 \%$ of these survived transplanting. Further examination revealed that most of the layers (marcots) only callused and failed to root. The use of a good rooting medium (topsoil and sawdust in the ratio 1:1) enhanced root growth, but was of little real value because the plants rooted so poorly. In other words, root initiation is very poor in cashew layers. However, the process of rooting in cutting and the air-layer is characterized by initiation, elongation of root initials, and root growth and development [15]. Meanwhile, auxins have been reported to facilitate stem growth, adventitious root formation, and activation of cambial cells [16, 17]; hence the choice of auxins in our work with the main objective of improving rooting ability and ensuring better establishment of cashew clones.

In our paper, we report how three auxins of varying concentrations affected rooting and survival of cashew clones after transplanting. 


\section{Materials and methods}

Two accessions (CSI11 and CSI58) from a long adapted cashew Indian population, and two accessions (CSO07 and CSO20) from a recently introduced Brazilian population planted at the research plot of the Cocoa Research Institute of Nigeria, Ibadan, a rainforest ecology $\left(7^{\circ} 10^{\prime} \mathrm{N}\right.$, $\left.3^{\circ} 52^{\prime} \mathrm{E}\right)$, were selected and used in this study based on a previous characterization study [7]. The experimental plot consisted of three blocks (replicates) with each accession represented by three trees in each block. The trial was carried out as a randomized complete block design with three auxins: indole-3-butyric acid (IBA), indole-3-acetic acid (IAA) and napthalene1 -acetic acid (NAA), applied at six concentrations $[(0,1,2,3,4$ and 5$) \%]$ on the four selected cashew accessions. Each treatment was carried out on five layers and replicated three times. The trial was carried out in 2005 and repeated in 2006 to minimize environmental influence.

Cashew twigs of about 10-12 months old were selected based on previous studies $[14,18]$ and a mixture of sterilized topsoil and sawdust in [1:1] proportions was used as the rooting medium [18]. A strip of bark of between $0.5-0.6 \mathrm{~cm}$ wide was removed from the selected twigs about 20$25 \mathrm{~cm}$ from the tip of the shoot and a strand of twine was wound round the cut portion to prevent the exposed edges of the bark from healing over. An auxin solution was applied to this portion and two handfuls of rooting medium were thereafter placed over the incision and wrapped with a piece of polythene sheet, about 23$\mathrm{cm}$ long and $15-\mathrm{cm}$ wide. Data were collected on the percentage of layers taken (i.e. that remained green) on the mother tree after 21 days of layering, number of days to rooting, number of roots per layer, length of roots and percentage of clones that survived transplanting to soil. The two years' data were summarized and average values were statistically analyzed using analysis of variance of the split-split plot method and mean dispersion described by Steel and Torrie [19].

\section{Results and discussion}

The results of the analysis of variance carried out on the data showed that there was no significant difference between replications (table I); however, data obtained with rooting hormones (auxins), concentration and genotype were significantly different. Interactions among these three factors [(concentration $\times$ hormone), (genotype $\times$ hormone), (genotype $\times$ concentration) and (genotype $\times$ hormone $\times$ concentration)] showed similar significant differences. This observation suggests that auxin type, its concentration and the genetic make-up of the tree, and interactions of all these factors can individually, and/or in combination, influence rooting of layers in cashew.

The results regarding five variables recorded on cashew propagules across three auxins at six concentrations with four genotypes showed that IBA gave the best rooting, while IAA had the least rooting effect (table II). Among the various concentrations tested, layers treated with (1 to 3)\% of auxins rooted better than control (0\%). However, among the accessions selected, CSI58 (a high-yielding Indian variety) rooted the best (83.4\%) and recorded the highest survival after transplanting to the field (38\%), while the worst performance was recorded in Brazilian CSO07 with 47.8\% and 16.6\% layers taken and clonal survival after transplantation, respectively. In the overall experiments, out of about $64 \%$ of the layers that sprouted and rooted, only about 30\% survived after transplantation (table II). The broad performance in terms of wide range values (table II) exemplified the potential of the auxins as root promoters in cashew.

However, to identify the performance of each auxin across the five concentrations tested, mean values were computed from the analysis (table III). Our data showed that IBA at 2\% concentration gave the best performance with about $96 \%$ of layers and 78\% of clonal survival after transplantation, i.e. about five-fold that of untreated layers (0\%). Layers treated with 2\% IBA produced about 12 roots with around $12 \mathrm{~cm}$ length within 35 days of set. Although 3\% IBA ranked next to $2 \%$ in performance, however, there was 
Table I.

Analysis of variance (mean square values) of treatments and interactions for five variables regarding rooting of propagules and establishment of cashew clones, recorded on cashew layers.

\begin{tabular}{|c|c|c|c|c|c|c|}
\hline Source & $\begin{array}{l}\text { Degree } \\
\text { of freedom }\end{array}$ & $\begin{array}{l}\text { Layers taken } \\
\text { on mother tree } \\
(\%)\end{array}$ & Roots / layer & $\begin{array}{l}\text { Days } \\
\text { to rooting }\end{array}$ & $\begin{array}{l}\text { Length } \\
\text { of rooting } \\
\quad(\mathrm{cm})\end{array}$ & $\begin{array}{c}\text { Clonal survival } \\
\text { after transplanting } \\
(\%)\end{array}$ \\
\hline \multicolumn{7}{|l|}{ Main plot } \\
\hline Replication & 2 & $0.5046 \mathrm{~ns}$ & $0.3511 \mathrm{~ns}$ & 3.7222 ns & $0.0048 \mathrm{~ns}$ & 0.0972 ns \\
\hline Hormone & 2 & $0.6157^{\star \star}$ & $173.8213^{\star \star \star}$ & $42.2639^{\star \star}$ & $174.1468^{\star \star \star}$ & $5.5417^{\star \star}$ \\
\hline Main plot error & 4 & 0.0463 & 0.1843 & 0.8028 & 0.2130 & 0.0972 \\
\hline \multicolumn{7}{|l|}{ Sub-plot } \\
\hline Concentration & 5 & $9.1935^{\star \star \star}$ & $73.9316^{\star \star \star}$ & $79.1333^{\star \star \star}$ & $49.4975^{\star \star \star}$ & $3.1972^{\star \star \star}$ \\
\hline Concentration $\times$ hormone & 10 & $1.8602^{\star \star \star}$ & $47.4290^{\star \star \star}$ & $31.8306^{\star \star \star}$ & $27.3780^{\star \star \star}$ & $1.7639^{\star \star \star}$ \\
\hline Sub-plot error & 30 & 0.1379 & 0.4211 & 0.3426 & 0.1704 & 0.1361 \\
\hline \multicolumn{7}{|l|}{ Sub-sub-plot } \\
\hline Genotype & 3 & $13.4244^{\star \star \star}$ & $28.0686^{\star \star \star}$ & $64.8457^{\star \star \star}$ & $14.9195^{\star \star \star}$ & $1.0380^{\star \star}$ \\
\hline Genotype $\times$ hormone & 6 & $0.5540^{*}$ & $3.9301^{\star \star \star}$ & $1.6281^{\star \star \star}$ & $2.3429^{\star \star \star}$ & $0.5269^{*}$ \\
\hline Genotype $\times$ concentration & 15 & $0.4133^{*}$ & $2.0249^{\star \star \star}$ & $1.0568^{\star \star \star}$ & $0.8743^{\star \star \star}$ & $0.3454^{\star \star}$ \\
\hline Genotype $\times$ concentration $\times$ hormone & 30 & $0.4762^{*}$ & $1.7056^{\star \star \star}$ & $0.9503^{\star \star \star}$ & $0.4425^{\star \star \star}$ & $0.2898^{\star}$ \\
\hline Sub-sub-plot error & 15 & 0.1914 & 0.2674 & 0.3272 & 0.1668 & 0.1296 \\
\hline
\end{tabular}

\section{Table II.}

Mean and range values for five variables regarding rooting of propagules and establishment of cashew clones recorded on cashew layers across three auxins at six concentrations tested on four cashew genotypes.

\begin{tabular}{|c|c|c|c|c|c|}
\hline Factors & $\begin{array}{l}\text { Layers taken } \\
\text { on mother tree } \\
(\%)\end{array}$ & Roots / layer & $\begin{array}{l}\text { Days } \\
\text { to rooting }\end{array}$ & $\begin{array}{l}\text { Length } \\
\text { of rooting } \\
\quad(\mathrm{cm})\end{array}$ & $\begin{array}{c}\text { Clonal survival } \\
\text { after transplanting } \\
(\%)\end{array}$ \\
\hline \multicolumn{6}{|l|}{ Hormone / auxin } \\
\hline IBA & $70.0 \mathrm{a}$ & $5.02 \mathrm{a}$ & 52 b & $5.78 \mathrm{a}$ & $42.2 \mathrm{a}$ \\
\hline NAA & $64.8 \mathrm{ab}$ & $2.64 \mathrm{~b}$ & $66 \mathrm{a}$ & $4.43 \mathrm{~b}$ & $25.6 \mathrm{~b}$ \\
\hline IAA & $57.6 \mathrm{~b}$ & $2.09 \mathrm{c}$ & $68 \mathrm{a}$ & $3.85 c$ & $22.8 \mathrm{~b}$ \\
\hline \multicolumn{6}{|l|}{ Concentration (\%) } \\
\hline 0 & $65.8 \mathrm{c}$ & $1.83 \mathrm{c}$ & $70 \mathrm{~b}$ & $3.25 c$ & $16.8 \mathrm{c}$ \\
\hline 1 & $72.4 \mathrm{~b}$ & $4.13 \mathrm{~b}$ & $51 \mathrm{c}$ & $6.89 \mathrm{~b}$ & $46.4 \mathrm{~b}$ \\
\hline 2 & $86.4 \mathrm{a}$ & $6.76 \mathrm{a}$ & $42 d$ & $8.92 \mathrm{a}$ & $58.4 \mathrm{a}$ \\
\hline 3 & $73.6 \mathrm{~b}$ & $4.30 \mathrm{~b}$ & $48 \mathrm{c}$ & $6.54 \mathrm{~b}$ & $43.0 \mathrm{~b}$ \\
\hline 4 & $50.8 d$ & $1.61 \mathrm{c}$ & $72 \mathrm{~b}$ & $2.10 \mathrm{~d}$ & $13.2 \mathrm{c}$ \\
\hline 5 & $36.2 \mathrm{e}$ & $0.88 d$ & $90 \mathrm{a}$ & $0.38 \mathrm{e}$ & $3.4 \mathrm{~d}$ \\
\hline \multicolumn{6}{|l|}{ Genotype } \\
\hline CSI11(Indian) & $59.0 \mathrm{c}$ & $3.16 \mathrm{c}$ & $64 \mathrm{~b}$ & $4.20 \mathrm{c}$ & $33.0 \mathrm{~b}$ \\
\hline CSI58 (Indian) & $83.4 \mathrm{a}$ & $4.10 \mathrm{a}$ & $52 \mathrm{c}$ & $6.66 \mathrm{a}$ & $38.0 \mathrm{a}$ \\
\hline CSO07 (Brazilian) & $47.8 \mathrm{~d}$ & $2.35 d$ & $72 \mathrm{a}$ & $2.76 \mathrm{~d}$ & $16.6 \mathrm{c}$ \\
\hline CSO20 (Brazilian) & $67.4 \mathrm{~b}$ & $3.39 \mathrm{~b}$ & $61 \mathrm{~b}$ & $5.10 \mathrm{~b}$ & $33.2 \mathrm{~b}$ \\
\hline Mean & 64.2 & 3.25 & 62 & 4.68 & 30.2 \\
\hline Range & $20.0-100$ & $0.00-18.00$ & $34-105$ & $0.00-12.20$ & $0.00-80$ \\
\hline
\end{tabular}


Table III.

Mean values of five variables regarding rooting of propagules and establishment of cashew clones recorded on cashew layers based on each of three auxins tested at six different concentrations.

\begin{tabular}{|c|c|c|c|c|c|}
\hline Hormone / concentration (\%) & $\begin{array}{l}\text { Layers taken } \\
\text { on mother tree } \\
(\%)\end{array}$ & Roots / layer & $\begin{array}{l}\text { Days } \\
\text { to rooting }\end{array}$ & $\begin{array}{l}\text { Length } \\
\text { of rooting } \\
(\mathrm{cm})\end{array}$ & $\begin{array}{c}\text { Clonal survival } \\
\text { after transplanting } \\
(\%)\end{array}$ \\
\hline \multicolumn{6}{|l|}{ IBA } \\
\hline 0 & $65.8 \mathrm{~cd}$ & $1.83 \mathrm{e}$ & $70 \mathrm{a}$ & $2.25 \mathrm{e}$ & $13.0 \mathrm{e}$ \\
\hline 1 & $79.8 \mathrm{~b}$ & $5.25 \mathrm{c}$ & $45 c$ & $6.25 c$ & $58.0 \mathrm{c}$ \\
\hline 2 & $96.2 \mathrm{a}$ & $11.70 \mathrm{a}$ & $32 d$ & $12.08 \mathrm{a}$ & $78.4 \mathrm{a}$ \\
\hline 3 & $84.4 \mathrm{~b}$ & $7.34 \mathrm{~b}$ & $40 \mathrm{c}$ & $9.04 \mathrm{~b}$ & $65.0 \mathrm{~b}$ \\
\hline 4 & $59.6 \mathrm{~d}$ & $2.97 \mathrm{~d}$ & $55 \mathrm{~b}$ & $3.94 \mathrm{~d}$ & $28.0 \mathrm{~d}$ \\
\hline 5 & $34.2 \mathrm{e}$ & $1.03 \mathrm{e}$ & $72 \mathrm{a}$ & $1.13 f$ & $11.0 \mathrm{e}$ \\
\hline Mean & 70.0 & 5.02 & 52 & 5.78 & 42.23 \\
\hline \multicolumn{6}{|l|}{ NAA } \\
\hline 0 & $65.8 c$ & $1.83 \mathrm{~d}$ & $70 \mathrm{c}$ & $2.25 \mathrm{~d}$ & $13.0 \mathrm{~d}$ \\
\hline 1 & $88.4 \mathrm{a}$ & $6.41 \mathrm{a}$ & $44 \mathrm{f}$ & $9.54 \mathrm{a}$ & $57.0 \mathrm{a}$ \\
\hline 2 & $79.6 \mathrm{~b}$ & $4.36 \mathrm{~b}$ & $55 \mathrm{e}$ & $7.64 \mathrm{~b}$ & $49.4 a b$ \\
\hline 3 & $75.2 \mathrm{~b}$ & $2.38 \mathrm{c}$ & $62 d$ & $4.88 \mathrm{c}$ & 29.2 c \\
\hline 4 & $50.6 \mathrm{~d}$ & $0.54 \mathrm{e}$ & $82 \mathrm{~b}$ & $1.52 \mathrm{e}$ & $5.0 \mathrm{e}$ \\
\hline 5 & $29.2 \mathrm{e}$ & $0.33 \mathrm{e}$ & $95 a$ & $0.75 \mathrm{f}$ & $0.0 \mathrm{f}$ \\
\hline Mean & 64.8 & 2.64 & 68 & 4.43 & 25.6 \\
\hline \multicolumn{6}{|l|}{ IAA } \\
\hline 0 & $65.8 \mathrm{~b}$ & $1.83 \mathrm{c}$ & $70 \mathrm{c}$ & $2.25 \mathrm{~d}$ & $13.0 \mathrm{~d}$ \\
\hline 1 & $79.0 \mathrm{a}$ & $4.73 \mathrm{a}$ & $51 \mathrm{e}$ & $8.45 a$ & $49.0 \mathrm{a}$ \\
\hline 2 & $73.6 \mathrm{a}$ & $3.03 \mathrm{~b}$ & $57 d$ & $6.75 \mathrm{~b}$ & $40.2 \mathrm{~b}$ \\
\hline 3 & $57.4 \mathrm{c}$ & $1.85 \mathrm{c}$ & $60 d$ & $4.20 \mathrm{c}$ & $27.2 \mathrm{c}$ \\
\hline 4 & $45.0 \mathrm{~d}$ & $0.90 \mathrm{~d}$ & $84 \mathrm{~b}$ & $1.02 \mathrm{e}$ & $7.4 \mathrm{e}$ \\
\hline 5 & $25.0 \mathrm{e}$ & $0.21 \mathrm{e}$ & $98 a$ & $0.42 \mathrm{f}$ & $0.0 \mathrm{f}$ \\
\hline Mean & 57.6 & 2.09 & 70 & 3.85 & 22.8 \\
\hline
\end{tabular}

little or no difference between it and 1\%. However, 5\% IBA seems to be injurious as the layers treated with this concentration performed below the control: perhaps auxin solution at this concentration might be phytotoxic. We found that NAA and IAA solutions at $1 \%$ concentration were less effective compared with IBA at the same concentration (table III). Similarly to IBA, NAA and IAA solutions at concentrations above 3\% were characterized by decreased root quality and reduced survival rates, signifying that higher concentrations of auxins are generally injurious and phytotoxic to the layers.
Generally, genotype, rooting solutions (auxins) and their concentrations play a significant role in influencing rooting ability and survival of cashew clones. Although the effect of auxins on the percentage take of air-layers may not be very significant when compared with untreated layers, these substances improved root quality (more and longer roots) and reduced the length of time required for rooting significantly. With IBA, the percentage of clones that survived after transplanting to the field increased by $150 \%$, i.e., comparing IBA (42\%) with control (17\%) (table II). Layers treated with auxin 
solutions between $1-3 \%$ concentrations gave significant increase in rooting and establishment ability compared with untreated layers (0\%). Furthermore, IBA gave the best performance in terms of rooting quality (number, length and days to rooting) and rate of survival after transplant. This result was in line with those of Henrique et al., who recorded better rooting with IBA in Pinus caribaea cuttings [20]. Emphasizing the uniqueness of IBA over other auxins in enhancing rooting of vegetative propagules, Vander Krieken et al. suggested the possible synergistic function of exogenous IBA on the endogenous synthesis of IAA of the treated portion of the plant for increased rooting [21]. Our data further supported Hartmann et al. that IBA is the best auxin, with a wider concentration range than NAA, and is effective in promoting rooting of a large number of plant species [15]. Our results, however, differ from the opinion of Lopes et al. [22] that IBA does not influence rooting in cashew. Conceivably, the low concentrations $(0-0.5 \%)$ of IBA that were used could be responsible for the nonresponsiveness to IBA in that study. In addition, Bid and Mukherejee [23], and Chhonkar and Singh [24] reported improved rooting of mango layers (a member of the cashew family) by using $0.5 \%$ and $2 \%$ NAA and IBA. Similarly, Mneney and Mantell found IBA to be most effective in the formation of adventitious roots in micro-shoot explants of cashew [14]. Although IBA is the most widely used auxin for inducing rooting of tree species due to its good response over a wide range of species, previous studies on cashew have shown that NAA could equally be effective, thus supporting the results obtained in our work.

Worth noting in this work is the reduction in the period of rooting from 10 weeks in control $(0 \%)$ to about 5 weeks in layers treated with $2 \%$ IBA. Perhaps it would be appropriate to deduce that, in addition to vigorous and more roots being produced due to auxin application, reduction in the period of rooting gave the layers better chance of survival after transplant. We could describe the activity of auxin, especially IBA, as having increased the rate of mor- phogenesis of the cells at the point of incision through synergistic reaction with endogenous IAA, as opined by Vander Krieken et al. [21]. Our data showed that concentrations above 3\% were injurious to the layers and resulted in a low survival rate of the propagules. Roots developed by layers treated with higher concentrations were short, sturdy and clumped together, showing evidence of poor growth, and in some instances dried out completely despite occasional irrigation. The osmotic imbalance of the rooting medium may account for the dryness of the roots of layers treated with a higher concentration above 4\%. Hence, 1$3 \%$ auxin concentrations would be ideal for enhancing rooting in cashew propagules. In our study, the CSI58, CSO20 and CSI11 genotypes responded better in rooting than CSO07, thus underscoring the important role of genotype, i.e., some trees are more morphogenically active than others. George opined that growth and morphogenesis of the root is influenced by genotype to the extent that closely related varieties of plants can differ substantially in their individual responses [25]. Henrique et al., however, reported a significant correlation between organic compounds such as total sugar content, reducing sugar content and total phenol contents on the plant stem, and rooting [20]. Studies on the variation of these compounds in cashew trees to be selected for layering would further elucidate selection of candidate genotypes (with desirable traits) for cloning.

Our data confirm the important role of auxins in the improvement of the rooting ability and survival of cashew propagules after transplant, and can thus be proposed to cashew growers for adoption in their clonal propagation work. However, future work focusing on combination of these auxins (synergy) and plant growth retardants in combination with auxins as opined by other authors [26-28] would be worthwhile. This intervention is fundamental to addressing problems of poor yield in cashew fields through massive production of clones of high-yielding varieties and conservation of highly valued cashew genetic resources in the gene pool. 


\section{Acknowledgements}

The authors acknowledge the technical support of Mr. Victor Enagu of the Plant Breeding Group, Cocoa Research Institute of Nigeria, Ibadan, Nigeria.

\section{References}

[1] Nakasone H.Y., Paull R.E., Tropical fruits, CAB Int., Oxford, U.K., 1998.

[2] Ohler J.G., Cashew, Koninklijk Inst. Trop., Amst., Neth., 1979, 260 pp.

[3] Anon., Crop production statistics database division, FAO, Rome, Italy, 2008.

[4] Katinila N.A., Mfilinge A.G., Lamboll R., Topper C.P., Socio-economic studies undertaken in relation to cashew growing households, in: Knowledge transfer for sustainable tree crop development: A case history of Tanzanian Integrated Cashew Management Programme, Topper C.P., Kasuga L.J. (Eds.), BioHybrids Agrisyst. Ltd., Reading, U.K., 2003, pp. 61-83.

[5] Topper C.P., Caligari P.D.S., Camara M., Diaora S., Djaha A., Coulibay F., Asante A. K., Boamah A., Ayodele E.A., Adebola P.O., West African regional cashew survey report (Guinea, Guinea Bissau, Cote d'Ivoire, Ghana and Nigeria), Sustainable Tree Crop Programme (STCP) and Biohybrids Agrisyst. Ltd., 2001, Vol. 1., U.K., 110 p.

[6] Aliyu O.M., Phenotypic correlation and path coefficient analysis of nut yield and yield components in cashew, Silvae Genetica 55 (1) (2006) 19-24.

[7] Aliyu O.M., Characterization and compatibility studies in cashew (Anacardium occidentale L.), , Univ. Ilorin, Thesis, Ilorin, Nigeria, 2004, 266 p.

[8] Barros L.M., Cavalcante J.J.V., Paiva J.R., de Crisostomo J.R., Correa M.P.F., Lima A.C., Selecao de clones de cajueiro-anao para o plantio commercial no Estado do Ceara, Pesqui. Agropecu. Bras. 35 (11) (2000) 21972204.

[9] Martins P.J., Kasuga L.J., Variation in cashew tree yield in South-East Tanzania and the implication for management of cashew smallholding, Trop. Agric. 72 (1995) 261-268.

[10] Oliveira E.T., Propagacao vegetative de Pinus sp. Via cultura de tecido, Sao Paulo Univ. /
ESALQ, Diss., Piracicaba, Sao Paulo, Brazil, 1989.

[11] Coester W.A., Ohler J.G., Cashew propagation by cuttings, Trop. Agric. 53 (1976) 353358.

[12] Hore J.S., Sen S.K., Role of non-auxinic compounds and IBA on adventitious root formation in air-layers of cashew nut, Cashew 6 (1992) 11-15.

[13] Hore J.S., Sen S.K., Effect of non-auxinic compounds and NAA on adventitious root formation in layers of cashew, J. Plant. Crops 21 (1993) 114-115.

[14] Mneney E.E., Mantell S.H., In vitro culture of cashew (Anacardium occidentale L.), Tanzan. Agric. Res. Train. Newsl. XVI (1-4) (2001) 4-10.

[15] Hartmann H.T., Kester D.E., Davis F.T. Jr., Geneve R.L., Plant propagation: principles and practices, N.J., Prentice Hall, USA, 2002.

[16] Haissig B.E. Davis T.D., An historical evaluation of adventitious rooting research to 1993 , in: Davis T.D., Haissig B.E. (Eds.), Biology of adventitious root formation, Plenum Publ. Corp., N.Y., U.S.A., 1994, pp. 275-331.

[17] Went F.W., A test method for rizhocaline, the root-forming substance, Proc. K. Ned. Akad. Wet. 37 (1934) 445-455.

[18] Aliyu O.M., Clonal propagation in cashew (Anacardium occidentale L.): Effect of rooting media on the rootability and sprouting of airlayers, Trop. Sci. 47 (2) (2007) 65-72.

[19] Steel R.G., Torrie J.H., Principles and procedures of statistics, McGraw Hill, N.Y., U.S.A., 1988.

[20] Henrique A., Caminhos E.N., Ono E.O., de Pinho S.Z., Effect of plant growth regulators in the rooting of Pinus cuttings, Braz. Arch. Biol. Technol. 49 (2) (2006) 189-196.

[21] Van der Krieken W.M., Breteler H., Visser M.H.M., Mavridou D., The role of the conversion of IBA into IAA on root regeneration in apple: introduction of a test system, Plant Cell Rep. 12 (1993) 203-206.

[22] Lopes R.L., Cavalcante H.L., Oliveira I.V.D.M., Martins A.B.G., Indol-butyric acid levels on cashew cloning by air-layering process, Rev. Bras. Frutic. (Jaboticabal - SP) 27 (3) (2005) 517-518.

[23] Bid N.N., Mukherjee S.K., Varietal response to etiolation and growth regulator treatment in air-layering of mango, Indian J. Agric. Sci. 30 (1969) 1013-1019. 
[24] Chhonkar V.S., Singh R.K., Propagation of Mangifera indica L. by air-layering, Acta Hortic. 24 (1972) 89-92.

[25] George E.F., Plant propagation by tissue culture (Part 2: Practice), Exeg. Ltd., Edington, Wilts, U.K., 1996.

[26] Reddy Y.N., Majumdar P.K., Bottom heat: New technique for rooting hard wood cuttings of tropical fruits, Curr. Sci. 44 (1975) 444-445.
[27] Pan R., Zhao Z., Synergistic effects of plant growth retardants and IBA on the formation of adventitious roots in hypocotyl cuttings of mungbean, Plant Growth Regul. 14 (1994) 15-19.

[28] Wiesman Z., Lavee S., Enhancement of IBA stimulatory effect on rooting of olive cultivar stem cutting, Scientia Hortic. 65 (1995) 189198.

\section{¿Acaso pueden las axinas mejorar el enraizamiento de acodos, así como el establecimiento de clones de anacardo?}

Resumen - Introducción. La producción del anacardo está decayendo, debido a los bajos rendimientos, a su vez causados por la mala calidad de las poblaciones de anacardos que resultan de la siembra, obtenida por la polinización libre y empleada para establecer las plantaciones. Los clones establecidos a partir de individuos seleccionados, obtenidos por acodo aéreo, enraízan mal; y, no son aptos a la supervivencia de los trasplantes. Por ello, la propagación de clones mediante acodo aéreo resulta poco eficaz para la propagación del anacardo. Material y métodos. Para mejorar los porcentajes de enraizamiento a partir de acodo aéreo, se aplicaron tres axinas (AIB, ANA, y AIA) a seis concentraciones diferentes $[(0,1,2,3,4$ y 5)\%] sobre cuatro genotipos de anacardo: dos de origen indio y dos de origen brasileño. Resultados y discusión. Se registraron mejoras significativas en lo que se refiere a la toma de muestras de acodos, al número de raíces por acodo, al número de días para el enraizamiento, a la longitud de las raíces, así como al porcentaje de supervivencia de los clones tras ser trasplantados. Las mejoras variaron de acuerdo con las axinas experimentadas, con las concentraciones empleadas y con los genotipos sometidos a prueba. Observamos que el nivel de enraizamiento pertenecía específicamente al propio genotipo y que estaba influenciado por el tipo de axina y por su concentración. Nuestros resultados mostraron que, de las tres axinas sometidas a prueba, AIB era la más eficaz con un efecto óptimo a una concentración del 2\%. Conclusión. El empleo de axinas permitió mejorar significativamente el enraizamiento, así como la supervivencia de los acodos de anacardo. Sin embargo para la obtención de un enraizamiento suficiente, y de una mejor recuperación después de la trasplantación, la axina no debería aplicarse a una concentración superior al 3\%. Dicha intervención permitiría reducir el problema del establecimiento de los anacardos en el campo.

Nigeria / Anacardium occidental / propagación vegetativa / acodo / auxinas / establecimiento de plantas 